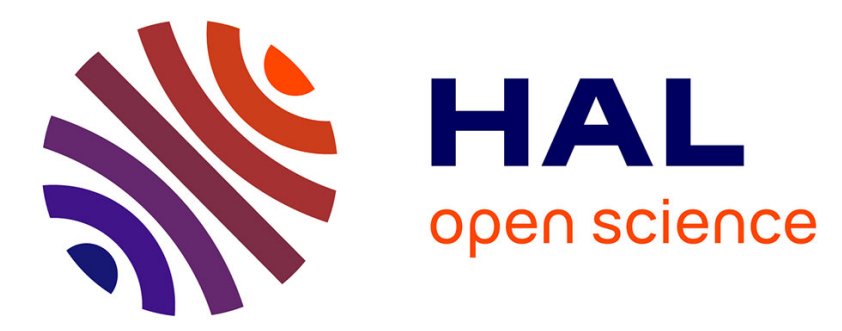

\title{
Consumer responses to elimination of overpackaging on private label products
}

Elisa Monnot, Fanny Reniou, Béatrice Parguel

\section{To cite this version:}

Elisa Monnot, Fanny Reniou, Béatrice Parguel. Consumer responses to elimination of overpackaging on private label products. International Journal of Retail and Distribution Management, 2015, 43 (4/5), pp.329-349. hal-01123706

\section{HAL Id: hal-01123706 https://hal.science/hal-01123706}

Submitted on 5 Mar 2015

HAL is a multi-disciplinary open access archive for the deposit and dissemination of scientific research documents, whether they are published or not. The documents may come from teaching and research institutions in France or abroad, or from public or private research centers.
L'archive ouverte pluridisciplinaire HAL, est destinée au dépôt et à la diffusion de documents scientifiques de niveau recherche, publiés ou non, émanant des établissements d'enseignement et de recherche français ou étrangers, des laboratoires publics ou privés. 


\author{
Elisa Monnot* \\ Thema, CNRS UMR 8184 \\ Université de Cergy-Pontoise \\ 33 boulevard du Port \\ 95011 Cergy Pontoise Cedex \\ France
}

Fanny Reniou

Institut de Recherche en Gestion

Université Paris-Est Créteil

Place de la Porte des Champs

4 route de Choisy

94010 Créteil Cedex

France

\author{
Béatrice Parguel \\ DRM UMR CNRS 7088 \\ Université Paris-Dauphine \\ Place du Maréchal de Lattre de Tassigny \\ 75775 Paris Cedex 16 \\ France
}

* Corresponding author: Elisa Monnot, elisa.monnot@u-cergy.fr 


\title{
Consumer responses to elimination of overpackaging on private label products
}

\begin{abstract}
Purpose - Eliminating overpackaging is a central question in sustainable development, and poses a dilemma for retailers. Since packaging is a differentiation tool for private labels, eliminating it could limit the capacity to give those labels an equivalent image to national brands just as much as it could be a sustainable development opportunity and a positioning instrument. Drawing on the attribution theory framework, this article examines how eliminating overpackaging influences consumers' perception of products sold under generic and mimic private labels, and their purchase intention.
\end{abstract}

Methodology - This research uses a 2 (overpackaging: present $v s$. absent) x 2 (brand concept: generic vs. mimic private label) between-subjects experiment on a convenience sample of 217 French consumers. The conceptual framework was tested using ANCOVA and mediation analyses.

Findings - Our experiment shows that eliminating overpackaging does have an influence on mimic private labels' image, particularly on perceived quality, convenience and environmental friendliness. We also find that this influence negatively transfers to purchase intention for mimic private labels through lower perceived quality and convenience. No such effect appears for generic private labels' image.

Value - This study addresses an issue as yet unexplored in marketing - the effect of overpackaging on private label products - and proposes areas for managerial and societal reflection relevant to retail chains interested in eliminating overpackaging.

Keywords: overpackaging, packaging, private label, product image, consumer behaviour 


\section{Introduction}

In the last few years, major large retailers have instigated several initiatives in favour of sustainable development, in response to increasing demand from both consumers and the public authorities (Schwepker and Cornwell, 1991; Burns and Brady, 1996; Thøgersen, 1999; Girod, 2003; Wiese et al., 2012). Consumers want to be green (Rokka and Uusitalo, 2008; Park and Ha, 2012). Ergo, retailers want to be green as well. One example in France is the supermarket chain Leclerc, which in 1996 was a pioneer of the move to stop handing out free carrier bags, and in 2010 announced that it would stop publishing advertising circulars by 2020. Meanwhile, Leclerc promoted a policy of simplified packaging for its private label (also known as own-brand) products, reducing the size and volume of packaging, selecting recyclable materials, eliminating overpackaging for yoghurt, toothpaste and mayonnaise (Leclerc, 2010). Since 2005, in the United Kingdom, the voluntary Courtauld Commitment has encouraged grocery retailers to reduce the weight and carbon impact of household food waste, product and packaging waste (from primary to tertiary packaging), both in the home and the grocery sector (Wrap, 2014). Retailers from several European countries therefore try to achieve reductions in packaging waste. Considering that 4.7 million tonnes of household packaging are thrown away every year in France, and the recycling rate is only $67 \%$ (ADEME, 2012), eliminating overpackaging, i.e. outer packaging designed to surround the product without any grouping of primary units, appears particularly appropriate, especially as the function of this type of packaging relates more to marketing than technical requirements.

Eliminating overpackaging on private label products nonetheless remains a sensitive question in view of the strategic issues these labels represent for retailers. Private labels pursue a dual objective for the store that sells them: the qualitative objective of enhancing the store's image, and the quantitative objective of generating higher margins (Kremer and Viot, 2012). Retailers are thus willing to make large-scale investments in their private labels to turn them into brands in their own right, with a specific positioning in the portfolios including generic, mimic and premium private labels (Huang and Huddleston, 2008). Each type of private labels provides consumers with specific features: (1) generics provide the lowest price, a minimalist packaging and low quality; (2) mimic brands provide low-priced products, a reasonable level of quality and similar packaging to national brands; (3) premium private labels provide high-quality products and sometimes even higher quality than national brands (Laaksonen and Reynolds, 1994; Huang and Huddleston, 2008). Private labels account for 
$40 \%$ of sales at Wal-Mart, $50 \%$ at Tesco and $95 \%$ at Aldi, and the private labels' percentage of penetration is high or very high for almost $50 \%$ of packaged consumer goods categories in France (Lincoln and Thomassen, 2009).

The question of eliminating overpackaging on private labels thus places retailers in a sort of dilemma. On one hand, there is a risk it might restrict profitability on these labels and the capacity to endow them with an equivalent image to national brands. Packaging is a crucial lever in the consumer's purchase decision, and this is particularly true of overpackaging because it is the most visible part of the product's packaging in-store, which is where the consumer makes $76 \%$ of his purchase decisions (Popai, 2012). As packaging is a way to differentiate products in a saturated selling environment (Wells et al., 2007), eliminating overpackaging on private label products could have negative consequences on their in-store evaluation and acceptability to consumers. On the other hand, it could be seen as an opportunity for retailers, providing both a response to growing stakeholder demand for a greater concern for sustainable development, and a positioning instrument. It could be a way to manage the private label portfolio, for instance by deciding to eliminate overpackaging on generic and mimic private labels. Some retailers are currently experimenting different directions to address the question of overpackaging. As an illustration, for its private label "Healthy Living" launched in January 2014, Tesco offers yoghurts either sold without any overpackaging or with a reduced overpackaging. To solve the dilemma posed by elimination of overpackaging, this study examines how eliminating packaging influences consumers' perceptions of products sold under private labels, and their purchase intention. As the question of eliminating overpackaging is less acute for premium private labels, which are more quality-oriented, and for which packaging design is particularly important (Wells et al., 2007), we focus on generic and mimic private labels.

To address this question, we draw on the literature on packaging and its communicative power, and also refer to attribution theory (Heider, 1944; 1958) to build a conceptual framework. We then test our hypotheses using a 2 (overpackaging: present vs. absent) x 2 (brand concept: generic vs. mimic private label) between-subjects experiment on a convenience sample of 217 French consumers. Univariate analyses are used to explain different products' perceptions (i.e. perceived quality, perceived expensiveness, perceived environmental friendliness and perceived convenience) and show that eliminating overpackaging does have an influence on mimic private labels' image, notably on perceived quality, environmental friendliness and convenience. Mediation analyses using Hayes' (2012) PROCESS macro also show that this influence negatively transfers to private labels' purchase 
intention through lower perceived quality and convenience. Our experiment also shows that no such effect appears for generic private labels' image. The conclusion discusses our theoretical contributions and highlights the implications for both academics and practitioners.

\section{Literature review}

A product's packaging fulfils both technical and marketing functions (Prendergast and Pitt, 1996). Technically, packaging exists to preserve product integrity by protecting it from damage caused by climatic, bacteriological and transit hazards (Stewart, 1995). In marketing terms, packaging is considered as a "silent salesman" (Pilditch, 1957). Consumers are exposed to the product's packaging in the store before they can directly experience consumption or use of the product (Orth and De Marchi, 2007). Because it describes and enhances the product to promote it to the final customer, packaging is a crucial tool in the purchase decision (Wigley and Chiang, 2009). Packaging is a very useful communication channel for the brand at the point of sale (Nancarrow et al., 1998; Hellström and Nilsson, 2011) because it can attract consumers' attention and influence the way they perceive the product's quality (Venter et al., 2011; Honea and Horsky, 2012). Packaging thus creates visual attention in the store (Schoormans and Robben, 1997; Pieters and Warlop, 1999), just at the point in time when the consumer makes most of his purchase decisions (Popai, 2012).

Research so far has concentrated on the influence of packaging features, i.e. extrinsic attributes used by the consumer when it is difficult to assess the product's intrinsic attributes. It was demonstrated very early on that packaging colour conveys meanings that directly influence product evaluation. As long ago as 1964, Dichter suggested that brown was associated with full-flavoured coffee, blue with milder coffee and yellow with the mildest coffee. In the same product category, Gordon, Finlay and Watts (1994) showed that a dark blue packaging suggested powerful flavour and higher quality. Research into packaging has also examined the effects of the shape of product packaging. In particular, this research suggests that shape influences the way consumers classify the product as belonging to a familiar product category (Berkowitz, 1987; Bloch, 1995), but also influences their beliefs about the product quality (Berkowitz, 1987; Schoormans and Robben, 1997) and their purchase behaviour. Yang and Raghubir (2005), for example, show that lengthening the packaging has a positive influence on perceived volume, and consequently a negative influence on the quantities purchased by consumers with low experience of the product. In 
addition to the packaging's colour and shape, placing a picture on the packaging facilitates instore product detection (Underwood et al., 2001). The inclusion of a picture also improves the presumed taste of the product (Underwood and Klein, 2002).

The mechanisms of packaging features' influence on product evaluation are based on use of heuristic cognitive shortcuts by the consumer. Since consumers are dealing with a complex sales environment and have to make decisions in a generally limited time, they tend to use simplified judgement rules to reduce cognitive effort (Payne et al., 1988). In the case of packaging, immediately visible features are visual clues that feed a relatively unconscious evaluation process (Mueller et al., 2010). For example, the perceived volume of packaging may depend solely on the perception that it has been lengthened (Raghubir and Krishna, 1999), and its general shape can encourage several inferences regarding other product attributes such as convenience, durability (Bloch, 1995), perceived quality (Berkowitz, 1987; Wang, 2013) and perceived expensiveness (Inman et al., 1990). As another example, packaging features (e.g. eco-labels) can be used as signals to inform consumers about product greenness (Rokka and Uusitalo, 2008; Atkinson and Rosenthal, 2014). Looking beyond the many different features of packaging, the actual presence of overpackaging, understood as packaging designed to surround products without grouping primary units together, has not to our knowledge been empirically researched. And yet this presence alone could also influence product evaluation under a similar set of heuristics, especially perceived quality, expensiveness, convenience and environmental friendliness.

\section{Conceptual framework}

On a theoretical level, attribution theory offers an appropriate conceptual framework to study the impact of eliminating overpackaging. This theory originated in 1944 with Heider, and seeks to explain how the individual makes sense of events he observes or in which he is an actor (Kelley, 1973). Attribution is defined as the individual's search for the causes of an event (Heider, 1958) in order to organise his perceptual field in a coherent, stable, meaningful way, and thus avoid cognitive dissonance (Festinger, 1957). Cognitive dissonance and attribution are thus related: attribution results from cognitive dissonance, which also influences the outcome of attribution. In this study, attribution theory casts light on consumer responses to elimination of overpackaging, for generic and mimic private labels. 


\section{Influence of eliminating overpackaging on private label product perceptions}

Based on cognitive evaluation of a product's intrinsic attributes, perceived quality refers to the evaluation of a product's excellence by the consumer (Chueh and Kao, 2004; Villarejo-Ramos and Sanchez-Franco, 2005). When it is difficult to assess the product's intrinsic attributes, particularly in the case of a quick, in-store decision, the consumer refers to extrinsic attributes such as packaging design (Bloch, 1995) to infer its quality level and expensiveness (Orth et al., 2010). For instance, the symbolism conveyed by packaging can be used to upscale positioning of the product or brand (Underwood, 2003), while a sophisticated packaging design can be associated with higher perceived price (Orth et al., 2010), and use of stickers can be associated with lower perceived price (Inman et al., 1990). In sum, the features of packaging are extrinsic attributes of the product: they influence consumer perceptions in terms of quality and expensiveness.

This signalling effect of packaging is especially relevant for private labels (Richardson et al., 1994; Underwood et al., 2001). In fact, "consumers are generally less familiar with the intrinsic attributes of private label brands, compared to more heavily advertised national brands" (Underwood and Klein, 2002, p. 61). Besides, though private label brands provide an increasing value for money in most European countries, consumers perceive store brands to be inferior to national brands on attributes such as overall quality, appearance, attractiveness, taste, aroma, and reliability (Bellizzi et al., 1981; Cunningham et al., 1982). Therefore, they rely more on extrinsic cues in evaluating private label brands than they do in evaluating national brands (Richardson, 1994).

In this study, we consider that overpackaging is such an extrinsic product attribute able to influence the way the product is perceived by the consumer. More specifically, we refer to attribution theory to consider how a consumer interprets the absence of overpackaging and identify a certain number of "attributions" (Weiner, 1979), i.e. causes to which it can be attributed. Perception of these causes will notably depend on the consumer's experience and knowledge.

Consumers may consider packaging features as generators of usefulness and signals of quality that could justify a price premium (Aydinliyim and Pangburn, 2012). They may also easily observe that national brand products, which are more expensive and supposed to be better quality, usually have overpackaging, whereas plain products, which are less elaborate and cheaper, do not. This may lead them to attribute the absence of overpackaging to lower quality, but also a lower product price. Furthermore, consumers are increasingly aware of the volume of waste their consumption generates (Arkes, 1996) and assign particular importance 
to use of environmentally-friendly packaging (Thøgersen, 1999; Rokka and Usitalo, 2008). As a result they may associate the absence of overpackaging with a commitment by the industrial manufacturer to move towards a certain selling simplicity in order to reduce its products' ecological impact (Williams and Wikstrom, 2011). Finally, products with little packaging are perceived as not very convenient for consumers (Aydinliyim and Pangburn, 2012): the packaging holds the products and protects them against potential damage during transport, storage and sale (McDaniel and Baker, 1977; Gonzalez et al., 2007; Wells et al., 2007; Sogn-Grundvag and Østli, 2009) as well as preventing contamination (Argo et al., 2006). Consequently, the presence of packaging can be associated with perception of the product as more convenient.

In the end, the mere presence of overpackaging can be attributed to causes relating to perceived product quality or the aim of making it easier to transport, consume or use, while the absence of overpackaging can be attributed to causes relating to the aim of making the product more environmentally-friendly or more economical. These perceived causes reflect the existence of cognitive responses that arise spontaneously during exposure to the product. The result of the attribution process is visible in modification of the brand's cognitive structure, in other words the beliefs associated with the brand. We thus expect the consumer to associate the existence of overpackaging with higher levels of quality, price and convenience, but lower respect for the environment. Overall, this suggests the following hypothesis:

$H_{1}$ : Eliminating overpackaging (a) reduces the perceived quality, (b) reduces the perceived expensiveness, $(c)$ increases the perceived environmental friendliness and $(d)$ reduces the perceived convenience of the product.

\section{Moderating effect of the type of private label}

Retailers develop private labels with different positionings, and bearing this in mind they may consider eliminating overpackaging for generic and mimic private labels. In this research we suggest that the type of private label can direct the locus of attribution towards a particular cause. Following this assumption, the effect of having no overpackaging would depend on the type of private label under consideration.

Retailers' own-brands have evolved from low-price, low-quality products to highprice, high-quality ones (Burt, 2000). In their portfolio, generic private labels are designed to cut down expenses on advertising, packaging and marketing; they provide consumers with the 
lowest possible price, a minimalist packaging and lower quality compared to national brands (Laaksonen and Reynolds, 1994; Huang and Huddleston, 2008). They offer simple "no frills" products which are sometimes sold in loose form, usually with low levels of marketing. The absence of overpackaging on generic private labels may therefore not surprise consumers, and not lead them to wonder about the reason for its absence. Yet attribution theory applies when the situation observed by the individual creates enough cognitive dissonance to drive the consumer to seek reasons for it (Lichtenstein and Burton, 1989). Otherwise, the consumer does not seek the reason for the absence of overpackaging, and does not change his beliefs about the product. Going further, even if the absence of overpackaging does trigger an attribution process, an obvious cause is available to the consumer (elimination of overpackaging is to reduce costs), which could distract him from any other type of internal attribution. As Kelley (1973) explains, attribution follows a "discounting principle" in which the influence of one specific cause is reduced by perception of obvious powerful alternative causes.

Mimic private labels, meanwhile, provide consumers with low-priced products of reasonably acceptable quality (Huang and Huddleston, 2008). Targeted to compete directly with manufacturers by mimicking leading national brands, they have similar packaging to national brands. The lack of overpackaging may in this case appear surprising to the consumer and create cognitive dissonance, which then triggers the search for its causes. Also, since mimic private labels do not automatically entail attribution to a cause such as the aim to reduce costs to bring down prices, the consumer may be led to change his beliefs about the product by attribution to other causes (i.e. quality, expensiveness, environmental friendliness, convenience).

From this discussion comes hypothesis $\mathrm{H}_{2}$, which posits that the absence of overpackaging has a greater influence on perceived quality, expensiveness, environmental friendliness, and convenience for a mimic private label product than a generic private label product:

$\mathrm{H}_{2}$ : The influence of eliminating overpackaging on the product's (a) perceived quality, (b) perceived expensiveness, (c) perceived environmental friendliness, and (d) perceived convenience depends on the private label concept: it should be stronger for a mimic private label than for a generic private label. 
Ajzen and Fishbein (1980) assert that an individual's behaviour results both from his attitude towards that behaviour, which itself depends on his beliefs, and the norm or social pressure to display such behaviour. Similarly, the attitude to a product depends on evaluation of the product's attributes and the importance assigned by the consumer to each attribute. Perceptions of a product's level of quality and its economic, environmental and practical features correspond to a set of beliefs about the product and should influence consumer behaviour towards it. As an illustration, several studies have found that consumers' perceptions of quality variations increase or decrease the likelihood of private label purchase (Batra and Sinha, 2000; Erdem et al., 2004). We therefore expect beliefs regarding the product's quality, expensiveness, environmental friendliness and convenience to have an impact on the consumer's purchase intention. Considering hypotheses $\mathrm{H}_{1}$ and $\mathrm{H}_{2}$, Hypothesis $\mathrm{H}_{3}$ is therefore formulated as follows:

$H_{3}$ : The influence of eliminating overpackaging on purchase intention is mediated by the product's (a) perceived quality, (b) perceived expensiveness, (c) perceived environmental friendliness and $(d)$ perceived convenience.

Figure 1 displays the proposed model.

(Place Figure 1 about here)

\section{Method}

\section{Experimental Design and Stimuli}

The experiment follows a 2 (overpackaging: present $v s$. absent) by 2 (brand concept: generic vs. mimic private label) between-subjects design. Across all conditions, participants were invited to observe a visual representation of a pack of four yoghurts, with and without overpackaging (see Appendix 1) and to complete a questionnaire. For the purpose of manipulation checks, we first asked respondents whether the product they were exposed to was overpackaged and the results showed a significant difference depending on the presence of overpackaging $\left(\mathrm{M}_{\text {presence }}=3.90\right.$ vs. $\left.\mathrm{M}_{\text {absence }}=2.37, p<.01\right)$.

We focused on France, where private label share is $30 \%$, which is average compared to other European countries; private labels shares vary from $16.8 \%$ in Italy to $50.5 \%$ in the UK (SymphonyIRI, 2012). We chose yoghurt as the product category to study because it is a 
consumer staple with very high penetration in the population: $44 \%$ for private label chilled products in France (GFK 2013); 96.7\% for yoghurts and 83.6\% for yoghurts under private labels in March 2013 (figures extracted by Nielsen on 9 April 2014). This product category also symbolically embodies the issue of reducing overpackaging (CNE, 2007a). We chose a real private label from one of the largest supermarket chains in France (Auchan), which sells private label products with different brand concepts, covering both generic and mimic private labels. This retailer's positioning is rather neutral compared with other supermarket chains. Manipulation of the brand concept is based on display of the "low cost" (premier prix) logo on the product with its "economical" positioning. This manipulation proved to be a success, as respondents perceived the generic private label product to be less expensive than the mimic private label product $\left(\mathrm{M}_{\text {generic }}=1.83\right.$ vs. $\left.\mathrm{M}_{\text {mimic }}=2.20, p<.01\right)$.

\section{Sample}

Data were collected through a face-to-face survey of 217 respondents. They were personally approached in the street in a major French city in March 2013. The final sample varies in terms of sex ( $48 \%$ female), age (mean $=37$, standard dev. $=17$ ), and socio-economic status. We randomly assigned subjects to one of the four treatments. Additional analyses showed that the four groups were homogenous in terms of $\operatorname{sex}\left(\chi_{(3)}^{2}=.58\right.$, ns), age $\left(\mathrm{F}_{(3,213)}=0.40, \mathrm{~ns}\right)$, product involvement $\left(\mathrm{F}_{(3,213)}=.88\right.$, ns $)$, environmental consciousness $\left(\mathrm{F}_{(3,213)}=2.08\right.$, ns $)$, and price sensitivity $\left(\mathrm{F}_{(3,213)}=1.83\right.$, ns $)$, which were included in analyses as individual control variables.

\section{Measures}

The respondents first assessed their purchase intention using items borrowed from Dodds et al. (1991): "If I was going to buy yoghurt, the chances of me buying this product would be high", "I want to buy this product", "If I was going to buy yoghurt, I would strongly consider buying this product", "If I was going to buy yoghurt, I would be very keen on buying this product" $($ Cronbach alpha $=0.878)$. To measure product evaluation and the individual covariables, we used adaptations of previously validated scales: perceived quality (Erdem and Swait, 1998), perceived expensiveness (Slonim and Garbarino, 1999), perceived environmental friendliness ( $\mathrm{ad}$ hoc items), perceived convenience (ad hoc items), product involvement (Author, 2010), environmental consciousness (Schwepker and Cornwell, 1991), and price sensitivity (Lichtenstein et al., 1993). All the constructs were measured by fivepoint Likert scales. We conducted unidimensionality and reliability checks for the multi-item 
scales and found satisfactory reliability. Appendix 2 lists the scales that were used in the experiment.

\section{Results}

\section{Univariate results}

To test $\mathrm{H} 1$ and $\mathrm{H} 2$, we ran successive ANCOVAS with overpackaging and the private label concept as factors, and product involvement, environmental consciousness, price sensitivity, age and sex as covariates, on the private label product perceptions.

As expected, eliminating overpackaging has a significant positive effect on perceived environmental friendliness $\left(\mathrm{F}_{(1,208)}=18.18, p<.01\right)$ and a significant negative effect on perceived convenience $\left(\mathrm{F}_{(1,208)}=5.80, p<.05\right)$. It has also a marginally significant positive effect on perceived expensiveness $\left(\mathrm{F}_{(1,208)}=2.73, p<.10\right)$ and a non-significant negative effect on perceived quality $\left(\mathrm{F}_{(1,208)}=2.04, p=.15\right)$. The data therefore corroborated $\mathrm{H}_{1 \mathrm{~b}}, \mathrm{H}_{1 \mathrm{c}}$ and $\mathrm{H}_{1 \mathrm{~d}}$, but not $\mathrm{H}_{1 \mathrm{a}}$. We also found a significant two-way interaction between overpackaging and the private label concept on perceived quality $\left(\mathrm{F}_{(1,208)}=6.35, p<.05\right)$ and perceived environmental friendliness $\left(\mathrm{F}_{(1,208)}=6.62, p<.05\right)$. No interaction effect appeared between overpackaging and the private label concept on perceived expensiveness $\left(\mathrm{F}_{(1,104)}=.04\right.$, $p=.83)$ and convenience $\left(\mathrm{F}_{(1,208)}=1.39, p=.24\right)$.

Table 1 reports the full ANCOVAS results and Figure 2 displays this pattern of results.

(Place Table 1 and Figure 2 about here)

Analyses conducted separately for each private label concept showed that the influence of eliminating overpackaging depends on the private label concept. More specifically, they showed a significant effect of eliminating overpackaging on perceived quality $\left(\mathrm{F}_{(1,104)}=7.54, p<.01\right)$, perceived environmental friendliness $\left(\mathrm{F}_{(1,104)}=24.83, p<.01\right)$, and perceived convenience $\left(\mathrm{F}_{(1,104)}=8.32, p<.01\right)$ for mimic private label products. As expected, contrast tests showed that overpackaged mimic private label products were associated with higher levels of quality $\left(\mathrm{M}=3.16\right.$ vs. $\left.2.72 ; \mathrm{F}_{(1,104)}=7.54, p<.01\right)$ and convenience $\left(\mathrm{M}=3.49\right.$ vs. $\left.2.82 ; \mathrm{F}_{(1,104)}=8.32, p<.01\right)$, but a lower level of environmental friendliness $\left(\mathrm{M}=2.75\right.$ vs. 3.57; $\left.\mathrm{F}_{(1,104)}=24.83, p<.01\right)$ than non-overpackaged mimic private label products. These effects did not appear for generic private label products 
$\left(\mathrm{F}_{\mathrm{s}(1,99)}=2.01, p_{s}>.10\right)$. Besides, though eliminating overpackaging seems to reduce both private label products perceived expensiveness (see Figure 2, panel B), the contrast analyses did not show any significant influence on perceived expensiveness for mimic private label products $\left(\mathrm{F}_{(1,104)}=.96, p=.33\right)$, nor for generic private label products $\left(\mathrm{F}_{(1,99)}=2.01, p=.16\right)$. $\mathrm{H}_{2 \mathrm{a}}, \mathrm{H}_{2 \mathrm{c}}$ and $\mathrm{H}_{2 \mathrm{~d}}$ are therefore corroborated, but not $\mathrm{H}_{2 \mathrm{~b}}$.

Table 2 displays contrast tests results.

(Place Table 2 about here)

\section{Mediation results}

Turning to the test of private label product perceptions as mediating variables explaining the effect of eliminating overpackaging on purchase intention, mediation analyses were conducted following the procedure proposed by Zhao et al. (2010) and Preacher and Hayes's (2008) macro. Private label concept was included as a moderator. Product involvement, environmental consciousness, price sensitivity, age and sex were controlled for and included as covariates. A bootstrapping procedure with 5000 samples helped counteract the assumption of normality of the sampling distribution of the indirect effect (ab), as required by the Sobel test (Hayes, 2009). Using Hayes' (2012) PROCESS macro (model 7), we specified a $95 \%$ confidence interval.

When exploring the influence of eliminating overpackaging on purchase intention for generic private labels, the results suggest no mediating effects of yoghurts perceptions, with the confidence interval of the indirect effect including "0" (Zhao et al., 2010). Regarding mimic private labels, and contrary to our expectations, perceived environmental friendliness and perceived expensiveness do not mediate the influence of eliminating overpackaging on purchase intention: $\mathrm{H}_{3 b}$ and $\mathrm{H}_{3 c}$ are therefore not supported. However, the indirect effect estimated by the bootstrapping process is significant and negative for perceived quality $(a b=-0.32$, with a resulting confidence interval from -0.5471 to -0.1008$)$ and perceived convenience ( $a b=-0.06$, with a resulting confidence interval from -0.1626 to -0.0119$)$. The fact that these confidence intervals do not include zero indicates a significant indirect effect and supports the case for mediation. All of the coefficients related to these two indirect effects (i.e. $a$ and $b)$ are significant $(p<0.05)$ or marginally significant $(p<0.06)$ and of the expected sign, supporting $H_{3 a}$ and $H_{3 d}$. Specifically, eliminating overpackaging reduces perceived quality and convenience, and even when controlling for overpackaging elimination, a unit increase in perceived quality enhances purchase intention by 0.66 units $(b=0.66, p<0.01)$ 
while a unit increase in perceived convenience enhances purchase intention by 0.11 units $(b=0.11, p<0.01)$.

\section{Discussion}

There has been a good deal of research into environmentally-friendly behaviour, especially buying "green" products (Lin and Chang, 2012; Olson, 2013) or ecologicallypackaged products (Schwepker and Cornwell, 1991; Rokka and Usitalo, 2008). To our knowledge, no research has considered the elimination of overpackaging, although that could contribute to the aim of reducing products' environmental impact (Thøgersen, 1999). In a pioneering attempt to evaluate the effects of eliminating overpackaging on private labels in the fast-moving consumer goods industry, this paper adds to the body of literature on sustainable retailing. It shows that eliminating overpackaging does have an influence on mimic private labels' image, notably on perceived quality, convenience and environmental friendliness, but for generic private labels it does not have any effect. It also shows that this influence negatively transfers to purchase intention for mimic private labels, through lower perceived quality and convenience. These results have some interesting theoretical and practical implications.

\section{Theoretical implications}

Regarding product packaging, past research indicates a contradiction. On one hand, packaging, and therefore a fortiori overpackaging, appears to have a key role in communication of brand identity and product evaluation (Underwood, 2003). On the other hand, its elimination does not appear to affect this evaluation, since it is considered as a way of cutting the amount of waste generated (Thøgersen, 1996). In looking at elimination of overpackaging and its impact on consumer responses as regards quality, expensiveness, environmental friendliness and convenience, this article provides additional arguments for the position defended by Underwood (2003). For example, it not only shows that eliminating overpackaging has an impact on the product's perceived quality, environmental friendliness and convenience; it also shows that this impact depends on the type of private label. Specifically, an impact on perceived quality, environmental friendliness and convenience is only observed for mimic private labels. Finally, for both product label concepts, eliminating 
overpackaging actually seems to reduce perceived expensiveness, but this effect is not significant when considering separately mimic and generic label products.

This study also shows that the influence of eliminating overpackaging on purchase intention is mediated by perceived quality and convenience, but not by perceived expensiveness and environmental friendliness. For perceived expensiveness, the effect is relatively marginal $(\mathrm{p}=0.16)$, possibly because the products selected in the experiment are fairly simple and may have been perceived as fairly cheap ( $M=1.02$ out of 5). Regarding the lack of mediating influence of perceived environmental friendliness, one explanation could be the "green marketing myopia" phenomenon (Ottman et al., 2006, p. 24), i.e. "marketers' myopic focus on their products' "greenness" over the broader expectations of consumers". Some research has even demonstrated the potential negative effects of products' green features on consumers' preference (Luchs et al., 2010; Kronrod et al., 2012). The product's "greenness" does not thus appear to be a sufficient argument to explain purchase intention in most consumers. To verify the relevance of this explanation, future research could consider the moderating nature of individual sensitivity to environmental protection, and test to see whether the product's perceived environmental friendliness could mediate the influence of eliminating overpackaging on purchase intention in the most environmentally-sensitive consumers.

Finally, this study enables us to reaffirm the power of attribution theory to understand consumer perceptions, particularly environmental perceptions relating to a sustainable development action.

\section{Practical implications}

This research provides an answer to the dilemma that may face brands. It shows that when overpackaging is eliminated, perceived quality only declines for mimic private labels. Retailers thus need to think about which components of the primary packaging should be reinforced, so as not to affect perceived quality. For generic private labels, the consumer attributes the absence of overpackaging to a coherent decision by the retailer to reduce costs, indicating that overpackaging is not a signal of better quality for these brands. Our results show that overpackaging can be legitimately eliminated without affecting the perceived quality of a product positioned as "economical", while reducing the production costs of overpackaging for the retailer. This study thus makes it possible to define an initial managerial framework concerning the conditions for elimination of overpackaging on private label products. Hesitant retailers could for instance decide to eliminate overpackaging 
provided they make sure, in the case of mimic private labels, that the primary packaging benefits from the same attributes as the overpackaging in terms of technical and marketing functions. It would therefore be advisable to consider communication campaigns focusing on the fact that product quality is unaffected when overpackaging is eliminated, and stressing the benefits for the product's other attributes (convenience, price, environmental friendliness). In a context where increasing consideration must be given to sustainable development, retailers could present elimination of overpackaging as a way of reducing the amount of waste and making selective waste disposal easier for consumers, who would no longer have to deal with this unnecessary packaging.

For example, when supermarket chain Leclerc eliminated overpackaging, it focused its communication campaign on cutting the price of products (e.g. a slogan for toothpaste was: "€1.03 with no box"), while fellow supermarket retailer Auchan emphasized the ecological argument (e.g. one of its slogan for chocolate mousses: "so that Elsa's shopping will create less waste, Auchan is reducing packaging on its products”). Only some communications, for instance by food manufacturer Danone, have taken the initiative of focusing on the product's perceived convenience: Danone stressed that the elimination of overpackaging on Activia brand products had no effect on the convenience and quality of the packaging, as the primary packaging had been redesigned (e.g. by making the pot lid stronger). Finally, Danone's les2Vaches brand opted to leave the overpackaging on its newly-launched products to maximise their marketing impact, i.e. their in-store visibility, then to eliminate it for environmental reasons after about a year, once the products were sufficiently well-known.

\section{Limitations and further research}

Despite its contributions, this study is not free of limitations. Firstly, it does not incorporate context effects relating to the fact that the products observed at points of sale are not currently homogeneous as regards the presence or absence of overpackaging on products. In this study respondents were presented with pictures of a single product that was not shown in a realistic in-store context. An experiment including such context effects could develop the study further by considering a real-life situation in which consumers find themselves facing several products, some with overpackaging and some without. Attribution theory could once again be highly relevant in this respect, reinforcing the importance of the environmental friendliness attribution and making it a habit for the sector, if all brands decided to eliminate overpackaging at the same time. 
Secondly, replications of this study should be considered, particularly in a different product category. Private label health and beauty products (such as toothpaste, skin creams, etc.) are affected by the overpackaging issue just as much as chilled products (CNE, 2007b) and may suffer from competition from national brands, which are also sold in the supermarkets as well as specialised stores. Given the completely different associations a consumer may make between a product (food or non-food) and the usefulness of its overpackaging, perceptions of quality, expensiveness, convenience and environmental friendliness could be affected. It would also be interesting to observe the effect of eliminating overpackaging on themed private labels, for example organic labels, since their consumption is associated with individual health and taste-related motivations, as well as collective environmental concern motivations (Schwartz and Bilsky, 1987; Zanoli and Naspetti, 2001). The absence of overpackaging on this type of private label product could thus be attributed to lower sensorial and health quality (Thompson, 1998), or a stronger environmental quality. Beyond these replications which could foster external validity of the experiment, it would be interesting to use a more reliable measure of convenience to increase its internal validity. Actually, apart from product protection, this concept also includes dimensions of transport, handling or storage, which can be of great importance for some product categories, such as hygiene products.

Thirdly, this study examines how eliminating overpackaging influences evaluation of private label products. It might also be interesting to see how it affects the retailer's image. Private labels are developed by retailers both to increase margins and enhance their image (Kremer and Viot, 2012). In this case, eliminating the overpackaging could play a role for the retailer's image, especially the perception of its commitment to sustainable development. This environmental commitment by retailers is particularly important due to their pivotal role between consumer demand and supplier output.

\section{Acknowledgments}

The authors would like to thank the anonymous reviewers for their insightful comments that greatly contributed to improving the final version of the paper. They would also like to thank the guest editor for his helpful comments and support during the review process. This research is included in Movida research program of French Ministry of Sustainable Development.

The names of the authors appear in alphabetical order. 


\section{References}

ADEME (2012), Emballages ménagers. Données 2012. Synthèse, available at: http://www2.ademe.fr/servlet/getBin?name=42CA39C16A8B7DB2FB714E1399328827_tom catlocal1388498479564.pdf (accessed 14 March 2014).

Ajzen, I. and Fishbein, M. (1980), Understanding attitudes and predicting social behavior, Prentice Hall, Englewood Cliffs, NJ.

Argo, J.J, Dahl, D.W. and Morales, A.C. (2006), "Consumer contamination: how consumers react to products touched by others", Journal of Marketing, Vol. 70 No. 2, pp. 81-94.

Arkes, H.R. (1996), "The psychology of waste", Journal of Behavioral Decision Making, Vol. 9 No. 3, pp. 213-224.

Author (2010)

Atkinson, L. and Rosenthal, S. (2014), "Signaling the green sell: the influence of eco-label source, argument specificity, and product involvement on consumer trust", Journal of Advertising, Vol. 43 No. 1, pp. 33-45.

Aydinliyim, T. and Pangburn, M.S. (2012), "Reducing packaging waste and cost via consumer price discounts", Decision Sciences, Vol. 43 No. 6, pp. 1063-1089.

Batra, R. and Sinha, I. (2000), "Consumer-level factors moderating the success of private label brands", Journal of Retailing, Vol. 76 No. 2, pp. 175-19.

Bellizzi, J.A., Knickeberg, H.F., Hamilton, J.R. and Martin, W.S. (1981), "Consumer perceptions of national private and generic brands", Journal of Retailing, Vol. 57 No. 4, pp. 56-70.

Berkowitz, M. (1987), "Product shape as a design innovation strategy", Journal of Product Innovation and Management, Vol. 4 No. 4, pp. 274-283.

Bloch, P.H. (1995), "Seeking the ideal form: product design and consumer response", Journal of Marketing, Vol. 59 No. 3, pp. 16-29.

Burns, D.J. and Brady, D.T. (1996), "Retail ethics as appraised by future business personnel in Malaysia and the United States", The Journal of Consumer Affairs, Vol. 30 No. 1, pp. 195-217.

Burt, S. (2000), "The strategic role of retail brands in British grocery retailing", European Journal of Marketing, Vol. 34 No. 8, pp. 875-90.

Chueh, T.Y. and Kao, D.T. (2004), "The moderating effect of consumer perception to the impacts of country-of-design on perceived quality", Journal of American Academy of Business, Vol. 4 No. 1/2, pp. 70-74. 
CNE (2007a), available at: http://www.premier-web.com/cne/new/wpcontent/uploads/2014/01/8.pdf (accessed 14 March 2014).

CNE (2007b), available at: http://www.premier-web.com/cne/new/wpcontent/uploads/2014/01/9.pdf (accessed 14 March 2014).

Cunningham, I.C.M., Hardy, A. P. and Imperia, G. (1982). "Generic brands versus national brands and store brands", Joumal of Advertising Research, Vol. 22 No. 5, pp. 25-32.

Dichter, E. (1964), Handbook of consumer motivation, McGraw-Hill, New York, NY.

Dodds, W.B., Monroe, K.B., and Grewal, D. (1991), "The effects of price, brand, and store information on buyers' product evaluations", Journal of Marketing Research, Vol. 28 No. 3, pp. 307-19.

Erdem, T. and Swait, J. (1998), "Brand equity as a signaling phenomenon", Journal of Consumer Psychology, Vol. 7 No. 2, pp. 131-157.

Erdem, T., Zhao, Y. and Valenzuela, A. (2004), "Performance of store brands: a cross-country analysis of consumer store-brand preferences, perceptions, and risk", Journal of Marketing Research, Vol. 41 No. 1, pp. 86-100.

Festinger, L. (1957), A theory of cognitive dissonance, Row, Peterson and Company, Evanston, Ill.

GFK (2013), available at: http://www.themavision.fr/jcms/rw_370498/les-mdd-en-france-en2013-quelles-strategies (accessed 14 March 2014).

Girod, M. (2003), "Branding in European retailing: a corporate social responsibility perspective", European Retail Digestive, Vol. 38 No. 1, pp. 1-6.

Gonzalez, M.P., Thorhsbury, S. and Twede, D. (2007), "Packaging as a tool for product development: communicating value to consumers", Journal of Food Distribution Research, Vol. 38 No. 1, pp. 61-66.

Gordon, A., Finlay, K. and Watts, T. (1994), "The psychological effects of colour in consumer product packaging", Canadian Journal of Marketing Research, Vol. 13, pp. 311 .

Hayes, A.F. (2009), "Beyond Baron and Kenny: statistical mediation analysis in the New Millennium", Communication Monographs, Vol. 76 No. 4, pp. 408-420.

Hayes, A.F. (2012), "PROCESS: a versatile computational tool for observed variable mediation, moderation, and conditional process modeling" [White paper], available at: http://www.afhayes.com/public/process2012.pdf (accessed 24 November 2012).

Heider, F. (1944), "Social perception and phenomenal causality", Psychological Review, Vol. 51 No. 6, pp. 358-374. 
Heider, F. (1958), The psychology of interpersonal relations, Wiley, New York, NY.

Hellström, D. and Nilsson, F. (2011), "Logistics-driven packaging innovation: a case study at IKEA", International Journal of Retail \& Distribution Management, Vol. 39 No. 9, pp. 638-657.

Honea, H. and Horsky, S. (2012), "The power of plain: intensifying product experience with neutral aesthetic context", Marketing Letters, Vol. 23 No. 1, pp. 223-235.

Huang, Y. and Huddleston, P. (2008), "Retailer premium own-brands: creating customer loyalty through own-brand products advantage", International Journal of Retail \& Distribution Management, Vol. 37 No. 11, pp. 975-992.

Inman, J.J., McAlister, L. and Hoyer, W.D. (1990), "Promotion signal: proxy for a price cut?", Journal of Consumer Research, Vol. 17 No. 1., pp. 74-81.

Kelley, H.H. (1973), "The processes of causal attribution", American Psychologist, Vol. 28 No. 2, pp. 107-128.

Kremer, F. and Viot, C. (2012), "How store brands build retailer brand image", International Journal of Retail \& Distribution Management, Vol. 40 No. 7, pp. 528-543.

Kronrod, A., Grinstein, A. and Wathieu, L. (2012), "Go green! Should environmental messages be so assertive?", Journal of Marketing, Vol. 76 No. 1, pp. 95-102.

Laaksonen, H. and Reynolds, J. (1994), "Own-brands in food retailing across Europe", Journal of Brand Management, Vol. 2 No. 1, pp. 37-46.

Leclerc (2010), available at: http://www.mouvement-leclerc.com/page/eco-conceptionreduction-des-emballages-1 (accessed 14 March 2014).

Lichtenstein, D.R. and Burton, S. (1989), "The relationship between perceived and objective price-quality", Journal of Marketing Research, Vol. 26 No. 4, pp. 429-443.

Lichtenstein, D.R., Ridgway, N.M. and Netemeyer, R.G. (1993), "Price perceptions and consumer shopping behavior: a field study", Journal of Marketing Research, Vol. 30 No. 2, pp. 234-245.

Lin, Y.-C. and Chang, C.-C.A. (2012), "Double standard: the role of environmental consciousness in green product usage", Journal of Marketing, Vol. 76 No. 5, pp. 125-134.

Lincoln, K. and Thomassen, L. (2009), Private label: turning the retail brand threat into your biggest opportunity, Kogan Page Publishers, London.

Luchs, M.C., Naylor, R.W., Irwin, J.R., and Raghunathan, R. (2010), "The sustainability liability: potential negative effects of ethicality on product preference", Journal of Marketing, Vol. 74 No. 5, pp. 18-31. 
McDaniel, C. and Baker, R.C. (1977), "Convenience food packaging and the perception of product quality", Journal of Marketing, Vol. 41 No. 4, pp. 57-58.

Mueller, S., Lockshin, L. and Jordan, J.L. (2010), "What you see may not be what you get: asking consumers what matters may not reflect what they choose", Marketing Letters, Vol. 21 No. 4, pp. 335-350.

Nancarrow, C., Wright, L.T. and Brace, I. (1998), "Gaining competitive advantage from packaging and labelling in marketing communications", British Food Journal, Vol. 100 No. 2, pp. 110-20.

Olson, E. (2013), "It's not easy being green: the effects of attribute tradeoffs on green product preference and choice, Journal of the Academy of Marketing Science, Vol. 41 No. 2, pp. 171-184.

Orth, U.R. and De Marchi, R. (2007), "Endurance of advertising-evoked brand image beliefs in the face of product trial", Journal of Food Products Marketing, Vol. 13 No. 1, pp. 3144.

Orth, U.R., Campana, D., and Malkewitz, K. (2010), "Formation of consumer price expectation based on package design: attractive and quality routes", Journal of Marketing Theory and Practice, Vol. 18 No. 1, pp. 23-40.

Ottman, J.A., Stafford, E.R. and Hartman, C.L. (2006), "Avoiding green marketing myopia: ways to improve consumer appeal for environmentally preferable products", Environment, Vol. 48 No. 5, pp. 22-36.

Park, J. and Ha, S. (2012), "Understanding pro-environmental behavior: a comparison of sustainable consumers and apathetic consumers", International Journal of Retail \& Distribution Management, Vol. 40 No. 5, pp. 388-403.

Payne, J.W., Bettman, J.R. and Johnson, E.J. (1988), "The adaptive decision-maker: effort and accuracy in choice", Journal of Experimental Psychology: Leaming. Memory, and Cognition, Vol. 14 No. 3, pp. 534-53.

Pieters, R. and Warlop, L. (1999), "Visual attention during brand choice: the impact of time pressure and task motivation", International Journal of Research in Marketing, Vol. 16 No. 1, pp. 1-16.

Pilditch, J. (1957), The silent salesman: how to develop packaging that sells, B.T. Batsford Limited, London.

Popai (2012), available at: http://faitesdescatalogues.fr/wp-content/uploads/2012/05/EtudeShopper_Engagement-Popai-2012.pdf (accessed 14 March 2014). 
Preacher, K.J. and Hayes, A.F. (2008), "Asymptotic and resampling strategies for assessing and comparing indirect effects in multiple mediator models", Behavior Research Methods, Vol. 40 No. 3, pp. 879-891.

Prendergast, G. and Pitt, L. (1996), "Packaging, marketing, logistics and the environment: are there trade-offs", International Journal of Physical Distribution and Logistics Management, Vol. 26 No. 6, pp. 60-72.

Raghubir, P. and Krishna, A. (1999), "Vital dimensions in volume perception: can the eye fool the stomach?", Journal of Marketing Research, Vol. 36 No. 3, pp. 313-326.

Richardson, P.S. (1994), "Cue effects on evaluations of national and private-label brands", in Park C.W. and Smith D.C. (Ed.), Marketing Theory and Applications, Vol. 5, AMA, Chicago, IL., pp. 165-171.

Richardson, P.S., Dick, A. and Jain, A.K. (1994), "Extrinsic and intrinsic cue effects on perceptions of store brand quality", Journal of Marketing, Vol. 58 No. 4, pp. 28-36.

Rokka, J. and Uusitalo, L. (2008), "Preference for green packaging in consumer product choices: do consumers care?", International Journal of Consumer Studies, Vol. 32 No. 5, pp. 516-525.

Schwartz, S.H. and Bilsky, W. (1987), "Toward a universal psychological structure of human values", Journal of Personality and Social Psychology, Vol. 53 No. 3, pp. 550-562.

Schoormans, J.P.L. and Robben, H.S.J. (1997), "The effect of new package design on product attention, categorization and evaluation", Journal of Economic Psychology, Vol. 18 No. 2/3, pp. 271-287.

Schwepker, C.H. and Cornwell, B.T. (1991), "An examination of ecologically concerned consumers and their intention to purchase ecologically packaged products", Journal of Public Policy \& Marketing, Vol. 10 No. 2, pp. 77-101.

Slonim, R. et Garbarino, E. (1999), "The effect of price history on demand as mediated by perceived price expensiveness", Journal of Business Research, Vol. 45 No. 1, pp. 1-14.

Sogn-Grundvag, G. and Østli, J. (2009), "Consumer evaluation of unbranded and unlabelled food products: the case of bacalhau", European Journal of Marketing, Vol. 43 No. 1/2, pp. 213-228.

Stewart, B. (1995), Packaging as an effective marketing tool, Pira International, Surrey. SymphonyIRI (2012), available at: http://www.symphonyiri.eu/Portals/0/articlepdfs/PrivateLabel/PrivateLabel_2012_FullRep ort_Final.pdf\#zoom=75 (accessed 11 July 2014). 
Thøgersen, J. (1996), "Wasteful food consumption. Trends in food and packaging waste", The Scandinavian Journal of Management, Vol. 12 No. 3, pp. 291-304.

Thøgersen, J. (1999), "The ethical consumer. Moral norms and packaging choice", Journal of Consumer Policy, Vol. 22 No. 4, pp. 439-460.

Thompson, G. (1998), "Consumer demand for organic foods: what we know and what we need to know", American Journal of Agricultural Economics, Vol. 80 No. 5, pp. 11131118 .

Underwood, R.L. (2003), "The communicative power of product packaging: creating brand identity via lived and mediated experience", Journal of Marketing Theory and Practice, Vol. 11 No. 1, pp. 62-76.

Underwood, R.L. and Klein, N.M. and Burke, R. (2001), "Packaging communication: attentional effects of product imagery, Journal of Product and Brand Management, Vol. 10 No. 7, pp. 403-422.

Underwood, R.L. and Klein, N.M. (2002), "Packaging as brand communication: effects of products pictures on consumer responses to the package and brand", Journal of Marketing Theory and Practice, Vol. 10 No. 4, pp. 58-68.

Venter, K., van der Merwe, D., de Beer, H., Kempen, E. and Bosman, M. (2011), "Consumers perceptions of food packaging: an exploratory investigation in Potchefstroom, South Africa", International Journal of Consumer Studies, Vol. 35 No. 3, pp. 273-281.

Villarejo-Ramos, A.F. and Sanchez-Franco, M.J. (2005), "The impact of marketing communication and price promotion on brand equity", The Journal of Brand Management, Vol. 12 No. 6, pp. 431-444.

Wang, E.S.T. (2013), "The influence of visual packaging design on perceived food product quality, value and brand preference", International Journal of Retail \& Distribution Management, Vol. 41 No 10, pp. 805-816.

Weiner, B. (1979), "A theory of motivation for some classroom experiences", Journal of Educational Psychology, Vol. 71 No. 1, pp. 3-25.

Wells, L.E., Farley, H. and Armstrong, G.A. (2007), "The importance of packaging design for own-label food brands", International Journal of Retail \& Distribution Management, Vol. 35 No. 9, pp. 677-690.

Wiese, A., Kellner, J., Lietke, B., Toporowski, W. and Zielke, S. (2012), "Sustainability in retailing - a summative content analysis", International Journal of Retail \& Distribution Management, Vol. 40 No. 4, pp. 318-335. 
Wigley, S. and Chiang, C.-L.R. (2009), "Retail internationalisation in practice: per una in the UK and Taiwan", International Journal of Retail \& Distribution Management, Vol. 37 No. 3, pp. 250-270.

Williams, H. and Wikstrom, F. (2011), "Environmental impact of packaging and food losses in a life cycle perspective: a comparative analysis of five food items", Journal of Cleaner Production, Vol. 19 No. 1, pp. 43-48.

Wrap (2014), available at: http://www.wrap.org.uk/node/14507 (accessed on 9 July 2014)

Yang, S. and Raghubir, P. (2005), "Can bottles speak volumes? The effect of package shape on how much to buy", Journal of Retailing, Vol. 81 No. 4, pp. 269-281.

Zanoli, R. et Naspetti, S. (2001), "Consumer motivations in the purchase of organic food: a means-end approach", British Food Journal, Vol. 104 No. 8, pp. 643-653.

Zhao, X., Lynch, J.G., and Chen, Q. (2010), "Reconsidering Baron and Kenny: myths and truths about mediation analysis", Journal of Consumer Research, Vol. 37 No. 2, pp. 197 206. 
Figure 1. Conceptual model

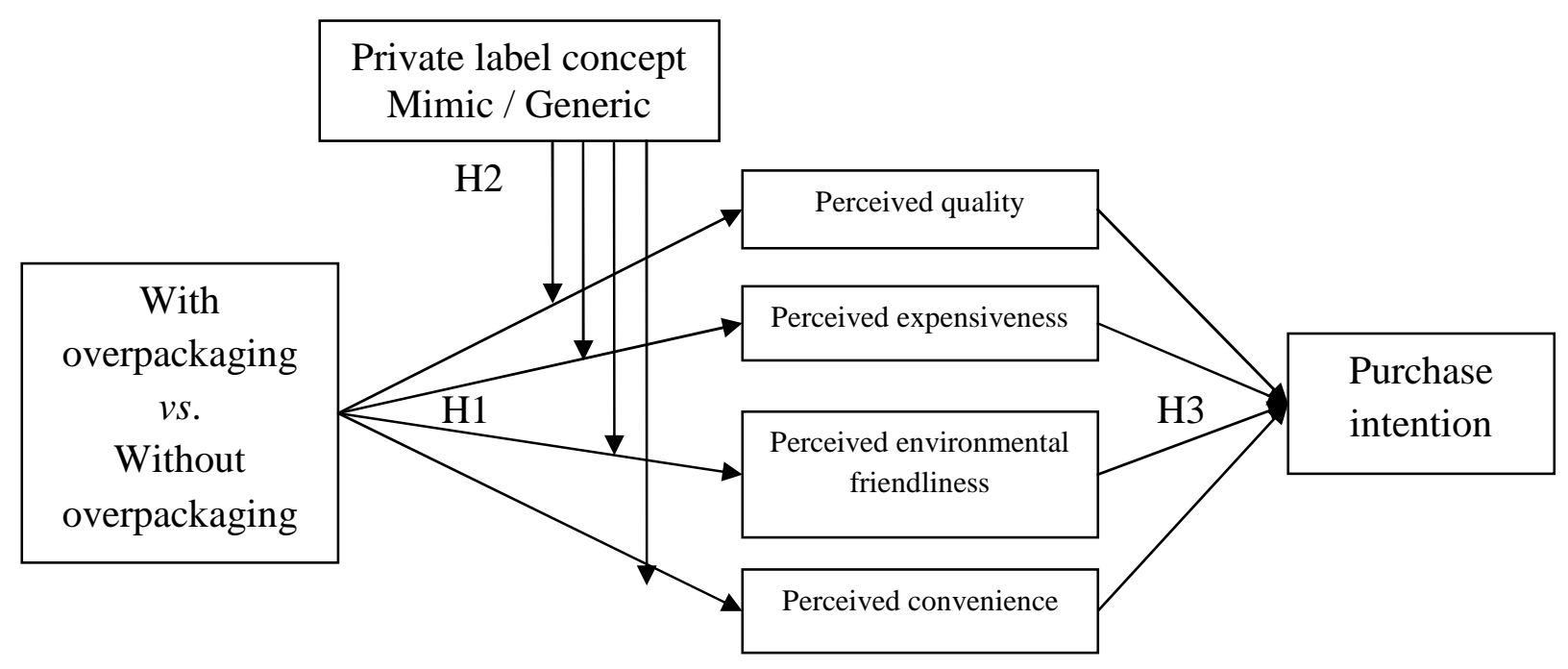


Figure 2. Two-way interaction between overpackaging and private label concept on private label product perceptions

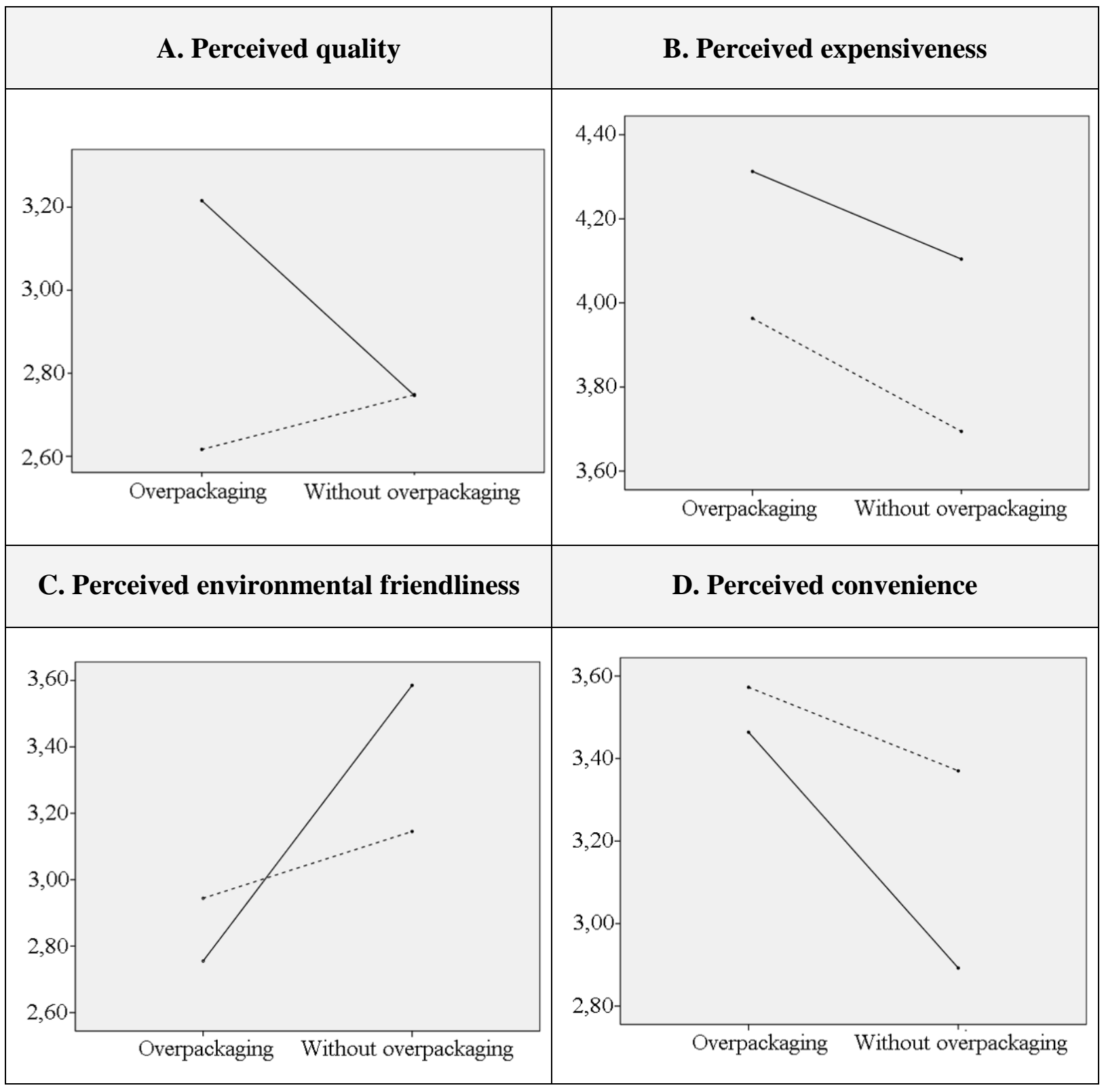

Notes: Mimic private label products are represented by an unbroken line, generic private label products by a dotted line. 
Table 1. ANCOVAS full results (F-ratios)

\begin{tabular}{cccc}
\hline Perceived & Perceived & $\begin{array}{c}\text { Perceived } \\
\text { envirommental }\end{array}$ & $\begin{array}{c}\text { Perceived } \\
\text { convenience }\end{array}$ \\
$\mathrm{F}_{(1,208)}$ & $\mathrm{F}_{(1,208)}$ & $\mathrm{F}_{(1,208)}$ & $\mathrm{F}_{(1,208)}$ \\
& & friendliness & \\
\hline
\end{tabular}

\begin{tabular}{|c|c|c|c|c|}
\hline \multicolumn{5}{|l|}{ Manipulated variables } \\
\hline $\begin{array}{l}\text { Overpackaging (with / } \\
\text { without) }\end{array}$ & 2.04 & $2.73^{+}$ & $18.18 * * *$ & $5.80 *$ \\
\hline $\begin{array}{l}\text { Private label concept (mimic / } \\
\text { generic) }\end{array}$ & $6.24 *$ & $6,73 *$ & 1.05 & $3.52^{+}$ \\
\hline $\begin{array}{l}\text { Overpackaging x Private label } \\
\text { concept }\end{array}$ & $6.35^{*}$ & .04 & $6.62 *$ & 1.39 \\
\hline \multicolumn{5}{|l|}{ Covariates in the ANCOVA } \\
\hline Product involvement & .37 & 1.96 & .00 & 1.23 \\
\hline Environmental consciousness & $6.68 *$ & .91 & 1.17 & .09 \\
\hline Price sensitivity & $16.13 * * *$ & .00 & .59 & 1.45 \\
\hline Sex & .16 & .92 & .38 & .67 \\
\hline Age & $5.38 *$ & $6.73 *$ & 1.77 & $3.40^{+}$ \\
\hline
\end{tabular}

Note: ${ }^{+} p<.10 ;{ }^{*} p<.05 ; * * p<.01 ; * * * p<.001$ (two-tailed). 
Table 2. Means and descriptive statistics by condition

\begin{tabular}{|c|c|c|c|c|c|c|c|c|c|}
\hline & \multicolumn{4}{|c|}{ Mimic private label } & \multicolumn{4}{|c|}{ Generic private label } & \multirow[b]{2}{*}{ Overall F } \\
\hline & $\begin{array}{c}\text { Mean with } \\
\text { overpackaging } \\
\text { (I) }\end{array}$ & $\begin{array}{l}\text { Mean without } \\
\text { overpackaging } \\
\text { (J) }\end{array}$ & $\begin{array}{l}\text { Contrast } \\
\text { value } \\
\text { (I-J) }\end{array}$ & t value & $\begin{array}{c}\text { Mean with } \\
\text { overpackaging } \\
\text { (I) }\end{array}$ & $\begin{array}{l}\text { Mean without } \\
\text { overpackaging } \\
\text { (J) }\end{array}$ & $\begin{array}{l}\text { Contrast } \\
\text { value } \\
\text { (I-J) }\end{array}$ & t value & \\
\hline $\begin{array}{l}\text { Purchase } \\
\text { intention }\end{array}$ & 2.54 & 2.41 & .13 & .50 & 2.44 & 2.63 & -.19 & 1.06 & .67 \\
\hline $\begin{array}{c}\text { Perceived } \\
\text { quality }\end{array}$ & 3.16 & 2.72 & .44 & $7.54 * *$ & 2.68 & 2.78 & -.10 & .34 & $4.92^{* *}$ \\
\hline $\begin{array}{c}\text { Perceived } \\
\text { expensiveness }\end{array}$ & 3.70 & 3.90 & -.21 & .96 & 4.02 & 4.31 & -.29 & 2.01 & $3.27 *$ \\
\hline $\begin{array}{c}\text { Perceived } \\
\text { environmental } \\
\text { friendliness }\end{array}$ & 2.75 & 3.57 & -.81 & $24.83 * * *$ & 2.96 & 3.16 & -.20 & 1.15 & $8.68 * * *$ \\
\hline $\begin{array}{l}\text { Perceived } \\
\text { convenience }\end{array}$ & 3.49 & 2.82 & .66 & $8.32 * *$ & 3.61 & 3.39 & .22 & .37 & $3.54 *$ \\
\hline $\begin{array}{c}\text { Descriptive } \\
\text { statistics }\end{array}$ & $\begin{array}{c}\mathrm{N}=50 \\
(52 \% \text { female, } \\
\text { mean age }=39)\end{array}$ & $\begin{array}{c}\mathrm{N}=56 \\
(46 \% \text { female, } \\
\text { mean age }=37)\end{array}$ & & & $\begin{array}{c}\mathrm{N}=57 \\
(46 \% \text { female, } \\
\text { mean age }=36)\end{array}$ & $\begin{array}{c}\mathrm{N}=54 \\
(50 \% \text { female, } \\
\text { mean age }=35)\end{array}$ & & & $\begin{array}{c}\mathrm{N}=217 \\
(48 \% \text { female, } \\
\text { mean age }=37)\end{array}$ \\
\hline
\end{tabular}

Note: ${ }^{+} p<.10 ; * p<.05 ; * * p<.01 ; * * * p<.001$ (two-tailed). 


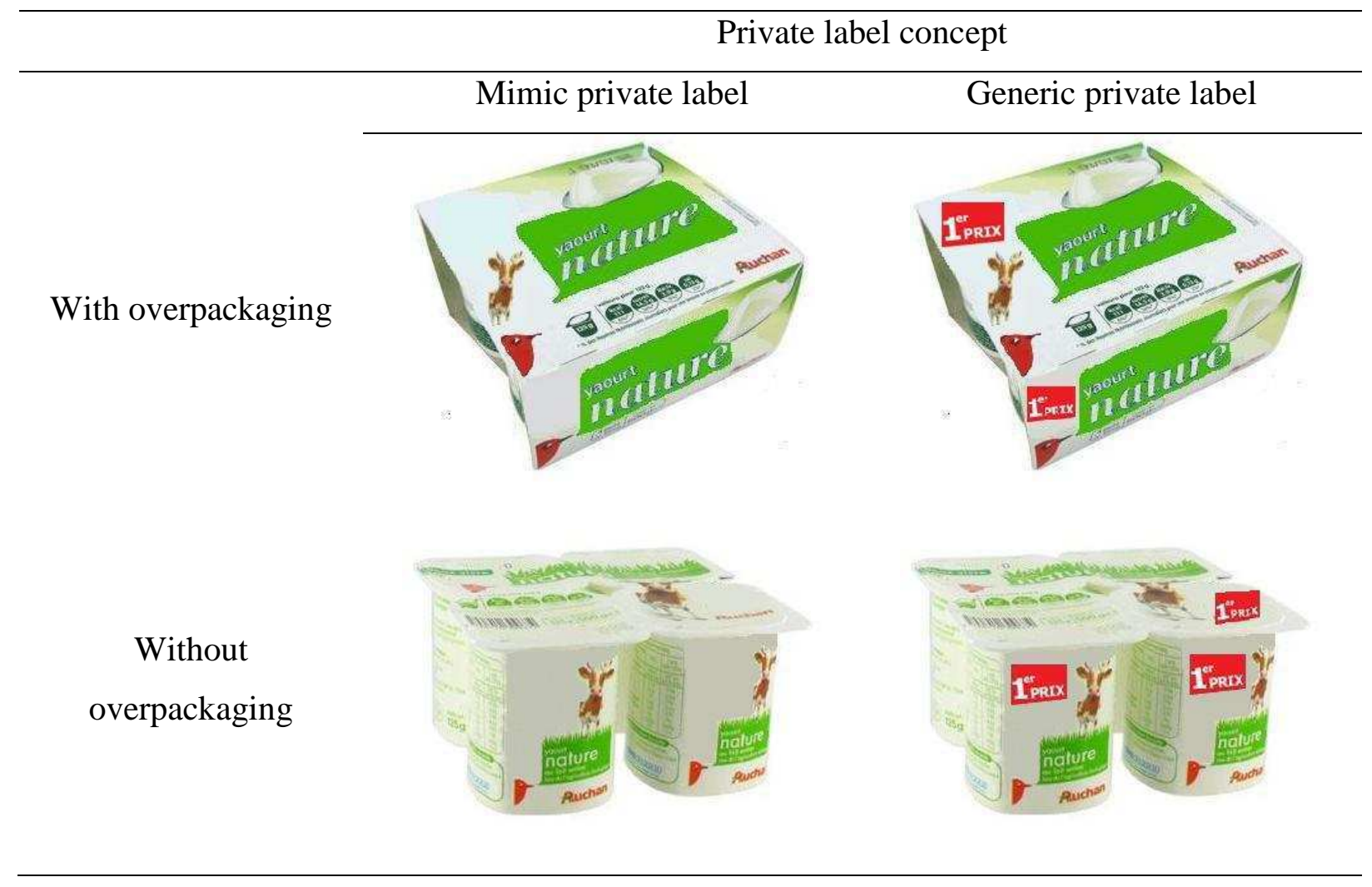


Appendix 2. Factor loadings, descriptive statistics, and reliability indices of the multi-item scales

\begin{tabular}{|c|c|c|c|c|c|c|c|}
\hline \multirow[b]{2}{*}{ Items } & \multicolumn{7}{|c|}{ Factors } \\
\hline & $\begin{array}{l}\text { Perceived } \\
\text { quality }\end{array}$ & $\begin{array}{c}\text { Perceived } \\
\text { expensiveness }\end{array}$ & $\begin{array}{c}\text { Perceived } \\
\text { environmental } \\
\text { friendliness }\end{array}$ & $\begin{array}{c}\text { Perceived } \\
\text { convenience }\end{array}$ & $\begin{array}{c}\text { Product } \\
\text { involvement }\end{array}$ & $\begin{array}{l}\text { Environmental } \\
\text { consciousness }\end{array}$ & $\begin{array}{c}\text { Price } \\
\text { sensitivity }\end{array}$ \\
\hline \multicolumn{8}{|c|}{ FACTOR LOADINGS } \\
\hline I think it's natural to spend time looking for the lowest prices & & & & & & & 0.921 \\
\hline I'm definitely willing to make efforts to find the cheapest products & & & & & & & 0.861 \\
\hline When I do my shopping, I always try to find the cheapest products & & & & & & & 0.823 \\
\hline The product looks poor quality to me & 0.852 & & & & & & \\
\hline I trust the quality of this product & 0.837 & & & & & & \\
\hline Buying this product means guaranteed quality & 0.790 & & & & & & \\
\hline $\begin{array}{l}\text { When I buy products, I think about the way my use will affect the } \\
\text { environment and other consumers }\end{array}$ & & & & & & 0.879 & \\
\hline I recycle waste whenever possible & & & & & & 0.771 & \\
\hline Whenever possible, I buy products I consider good for the environment & & & & & & 0.711 & \\
\hline This product is certainly more expensive than average & & 0.910 & & & & & \\
\hline Eating yoghurts is very important for me & & & & & 0.887 & & \\
\hline I consider the yoghourts I eat particularly important & & & & & 0.883 & & \\
\hline This product is environmentally friendly & & & 0.885 & & & & \\
\hline The product is ecological & & & 0.860 & & & & \\
\hline The product is definitely protected & & & & 0.957 & & & \\
\hline \multicolumn{8}{|l|}{ This product is convenient to transport $(*)$} \\
\hline \multicolumn{8}{|c|}{ SCALE VALUES AND RELIABILITY } \\
\hline Mean of scale & 2.84 & 3.98 & 3.11 & 3.32 & 3.92 & 2.96 & 2.86 \\
\hline SD & 0.93 & 1.07 & .93 & 1.24 & .97 & 1.01 & 1.11 \\
\hline Reliability ( $\alpha$ or $\rho$ ) & 0.793 & 0.690 & 0.540 & - & 0.595 & 0.709 & 0.854 \\
\hline
\end{tabular}

Notes: Extraction method: principal component analysis. Rotation method: varimax with Kaiser normalization

(*) This item was eliminated from the analysis because of a poor extracted communality 